\title{
Identifying Nonpoint Sources of Phosphorus and Nitrogen: A Case Study of Pollution That Enters a Freshwater Wetland (Laguna Cartagena, Puerto Rico)
}

\author{
Yashira Marie Sánchez-Colón ${ }^{1 *}$, Fred Charles Schaffner ${ }^{2}$ \\ ${ }^{1}$ Public Health Program, Ponce Health Sciences University, Ponce, Puerto Rico \\ ${ }^{2}$ School of Science and Technology, Ana G. Méndez University, Gurabo, Puerto Rico \\ Email: *ysanchez@psm.edu,fcspr@caribe.net
}

How to cite this paper: Sánchez-Colón, Y.M. and Schaffner, F.C. (2021) Identifying Nonpoint Sources of Phosphorus and Nitrogen: A Case Study of Pollution That Enters a Freshwater Wetland (Laguna Cartagena, Puerto Rico). Journal of Water Resource and Protection, 13, 588-604. https://doi.org/10.4236/jwarp.2021.138032

Received: June 29, 2021

Accepted: August 3, 2021

Published: August 6, 2021

Copyright $\odot 2021$ by author(s) and Scientific Research Publishing Inc. This work is licensed under the Creative Commons Attribution International License (CC BY 4.0).

http://creativecommons.org/licenses/by/4.0/

\begin{abstract}
Point and nonpoint sources of phosphorus $(\mathrm{P})$ and nitrogen $(\mathrm{N})$ can cause reductions in water quality, including eutrophication. Nonpoint pollution represents a special challenge because of dispersed not easily identifiable sources such as the runoff from soil, nutrients, and other chemicals from agricultural fields and residential areas. Laguna Cartagena is a tropical freshwater wetland, situated in southwestern Puerto Rico. It is a eutrophic ecosystem, and its eutrophication is caused by both external nutrient loading and internal, mainly by phosphorus. This wetland has been affected by phosphorus loading from inorganic agricultural fertilizer in this historically oligotrophic wetland system until the end of subsidized fertilizer use and sugar cane cultivation in the late 1990s. This study identifies: 1) nonpoint sources of phosphorus (SRP, Soluble Reactive Phosphorus and TP, Total Phosphorus) and nitrogen (nitrate, nitrite, and ammonia) that enter Laguna Cartagena; and 2) the role of precipitation events on the contributions of phosphorus and nitrogen loading to ecosystems. Herein we assess water samples from five channelized external sources of $\mathrm{P}$ and $\mathrm{N}$ that enter Laguna Cartagena at two-week intervals from October 2013 through November 2014. Rainfall data were obtained weekly from a rain gauge. Standard methods were used for all chemical analyses. Results showed that the channelized waterways that carry water to the lagoon can be classified as hypereutrophic $(>100 \mu \mathrm{g} / \mathrm{L})$ for TP concentrations and oligotrophic $(<200 \mu \mathrm{g} / \mathrm{L})$ for nitrogen concentrations. Currently agriculture (rice and cattle) is the predominant land use at the nearby University of Puerto Rico (UPR) Lajas Agricultural Experiment Substation, the predominant nonpoint source of nutrient pollution (SRP, TP and ammonia) in the
\end{abstract}


principal channelized water sources to the lagoon. Current nutrient loads are likely derived from fertilizers applied to the Substation's rice fields, and a high density livestock. The second important cause of external surface water degradation (SRP, TP and ammonia) is the discharge from rural households in the drainage basin that discharge greywater directly to the environment, as indicated by the results from Cerro Alto hills immediately to the north of the lagoon. Precipitation also was associated with SRP, TP and ammonia loads.

\section{Keywords}

Nonpoint Sources, Soluble Reactive Phosphorus, Total Phosphorus, Nitrogen Depleted, Eutrophication

\section{Introduction}

Wetlands are often considered "the kidneys of the watershed" because they provide many services to society, such as water quality improvement, recharging of water supplies including groundwater reservoirs, the buffering of river and stream discharge, and microclimate regulation [1] [2]. Wetlands also are characterized by their sediment retention, flood prevention, organic carbon and nutrient storage, timber production, the provision of non-timber products, medicinal plants, biodiversity support, providing drinking water for humans and livestock and offering opportunities for transport, recreation, ecotourism, and research [1].

Wetlands have been drastically altered by human disturbances, causing reductions in water quality including severe cultural eutrophication. Anthropogenic land use, due to economic development and population growth, influence phosphorus $(\mathrm{P})$ and nitrogen $(\mathrm{N})$ loads to waterbodies through both point and nonpoint sources [3], which can lead to eutrophication of surface water. Point sources of pollution are those which have a direct identifiable source, while nonpoint sources of pollution are those which arrive from various dispersed sources, such as the runoff of soil and sediments, nutrients, and other chemicals from agricultural fields, residential areas, and other lands [4] [5]. Nonpoint sources are difficult to control due to their diffuse nature that can be influenced by weather conditions [4].

Aquatic systems also can be affected by internal eutrophication in which $\mathrm{P}$ is released from wetland soils to the water column as a result of processes that are controlled by oxygen concentrations (including redox conditions, $\mathrm{pH}$, temperature) along with other drivers that are affected by changes in hydrology [6] [7]. In the eutrophic ecosystem of our Laguna Cartagena study site, for example, eutrophication is caused by both external nutrient loading and internal eutrophication, mainly of phosphorus.

Eutrophication or nutrient enrichment is a significant issue that results in water quality deterioration, stimulating excessive growth of plants and algae, high 
decomposition rates of the accumulated plant biomass, water acidification, decreased oxygenation and overall habitat degradation [1] [8] [9].

In aquatic environments, $\mathrm{P}$ exists in one oxidation state and occurs in particulate and soluble compartments as inorganic phosphate $\left(\mathrm{PO}_{4}^{3-}\right)$ or bound in organic molecules [10]. Soluble reactive phosphorus (SRP, inorganic phosphorus, orthophosphate (o- $\left.\mathrm{PO}_{4}^{3-}\right)$ ) is the only form of $\mathrm{P}$ that aquatic plants and algae can assimilate [10]. However, total phosphorus (TP) concentrations of 30 $100 \mu \mathrm{g} / \mathrm{L}(\mathrm{ppb})$ and $>100 \mu \mathrm{g} / \mathrm{L}(\mathrm{ppb})$, are considered eutrophic and hypereutrophic, respectively, for freshwater lakes [11].

In aquatic ecosystems, $\mathrm{N}$ processing includes volatilization, ammonification, nitrification-denitrification, plant, or microbial uptake (assimilation), sedimentation, dissimilatory nitrate reduction to ammonium (DNRA), anaerobic ammonium oxidation (ANNAMOX) and denitrification via sulfur oxidation [12] [13]. In natural waters the forms of nitrogen of greatest interest are nitrate $\left(\mathrm{NO}_{3}^{-}\right)$, nitrite $\left(\mathrm{NO}_{2}^{-}\right)$and ammonia $\left(\mathrm{NH}_{3}\right) . \mathrm{NO}_{3}^{-}$and $\mathrm{NO}_{2}^{-}$exist in the water in soluble forms. They can cause over-enrichment of a waterbody at elevated concentrations, while $\mathrm{NH}_{3}$ can cause direct toxic effects to aquatic life. The inorganic $\mathrm{N}$ and organic $\mathrm{N}$ concentrations of hypereutrophic aquatic ecosystems are $>1500 \mu \mathrm{g} / \mathrm{L}(\mathrm{ppb})$ and $>1200 \mu \mathrm{g} / \mathrm{L}(\mathrm{ppb})$, respectively [14].

Many factors exist that affect water quality, and change simultaneously, for example, precipitation, land use, agricultural management practices, and the specific ecological characteristics of lakes and streams [15]. Precipitation can increase the downstream transport of sediment, nutrients, base cations, organic matter, contaminants, and pathogenic microbes [16].

The objectives of the present work are to: 1) identify nonpoint sources of $\mathrm{P}$ (SRP and TP) and N (nitrate, nitrite, and ammonia) that enter Laguna Cartagena; and 2) identify the role of precipitation events on the contributions of $\mathrm{P}$ (SRP and TP) and N (nitrate, nitrite, and ammonia) loading to Laguna Cartagena.

\section{Materials and Methods}

\subsection{Description of the Study Site}

Laguna Cartagena (approximately 160 ha or about 400 acres) is a shallow (maximum depth $2 \mathrm{~m}$ ) freshwater lagoon and associated wetland situated in the Lajas Valley, Municipality of Lajas, in southwestern Puerto Rico and can be described as a eutrophic ecosystem.

The Laguna Cartagena ecosystem receives water (including pollutants) from multiple creeks, canals, and ditches. Margara Creek (or "Quebrada") is a natural stream that delivers water to Laguna Cartagena. Runoff is received from the east by Lago Loco near Yauco (several kilometers to the east) and flows from this reservoir through the Principal Irrigation Canal (irrigation source water) along the base of the adjacent northern hills and then to agricultural fields in the Lajas Valley. From there drainage water flows through the Principal Drainage Canal to 
Laguna Cartagena (Figure 1). In 1961, Margara Canal (the continuance of Margara Creek) was constructed to conduct unused irrigation water, some drainwater, and runoff from north of the lagoon in order to maintain lagoon water levels [17]. Margara Canal, and the Principal Drainage Canal adjacent to Road 305 at the UPR Lajas Agricultural Experiment Substation are the major channelized sources that bring water (both drainwater and runoff) to a single inlet canal, the Principal Drainage Canal in Laguna Cartagena, just to the west of the town of Magüayo, and then to the main body of the lagoon. The Principal Drainage Canal was constructed in 1950s and thus made Laguna Cartagena a permanent body of water [18] [19] [20] [21] [22]. This historically oligotrophic wetland system then continued to be directly affected by phosphorus loading from inorganic agricultural fertilizer until the end of subsidized fertilizer use and sugar cane cultivation in the late 1990s, although a legacy of these practices remains [21].

Laguna Cartagena has acted as both a sink and source of TP and SRP with internal phosphorus loading (internal eutrophication) from the lagoon's own sediments, causing higher phosphorus concentrations in lagoon water, and downstream to other ecosystems. This behavior has been influenced by external factors including water level fluctuations and rainfall and by intensified

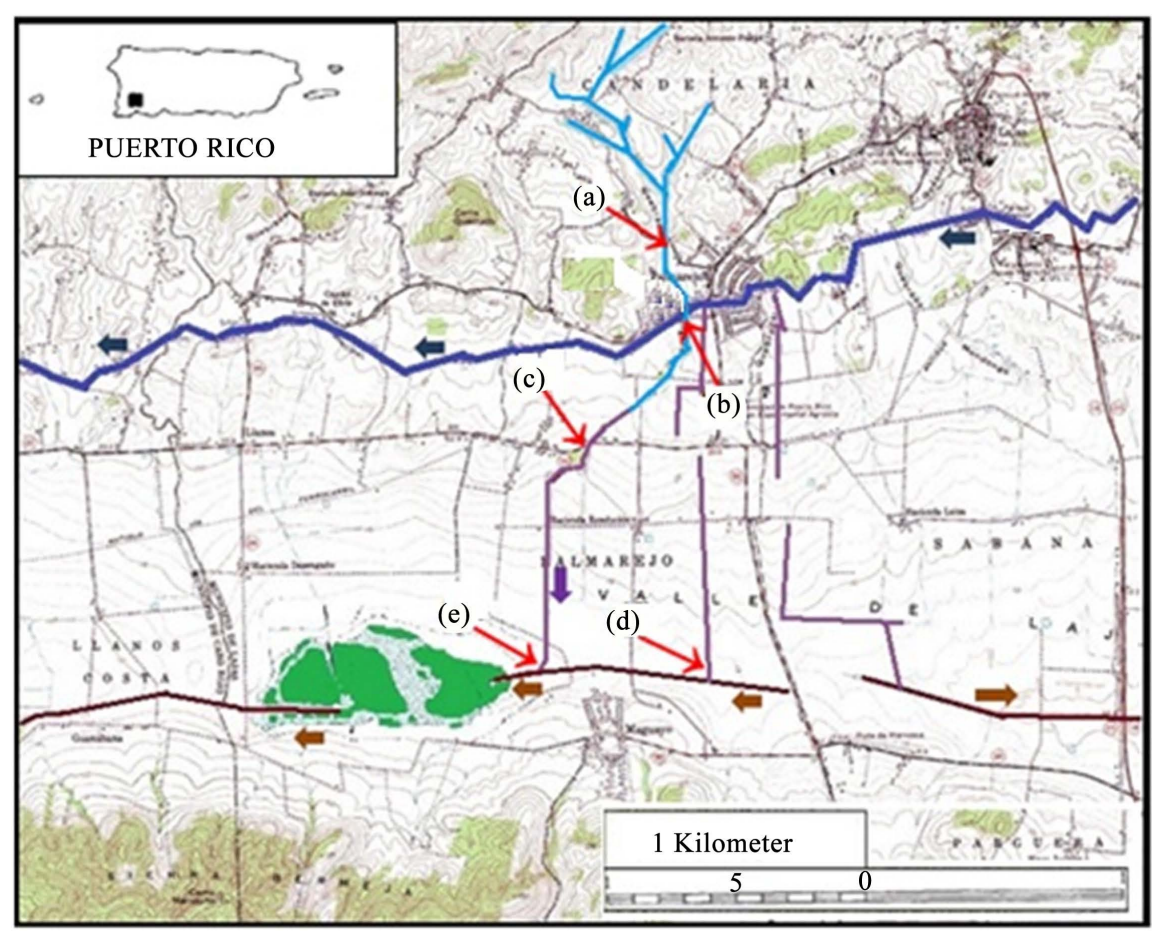

Figure 1. Channelized external influent water sources: (a) Cerro Alto; (b) Margara Creek immediately south of where it passes under Road 306 (parallel to the Principal Irrigation Canal (dark blue)); (c) Margara Canal-the continuance of Margara Creek; (d) Principal Drainage Canal adjacent to Road 305 at the UPR Lajas Agricultural Experiment Substation; (e) Principal Drainage Canal in the Refuge west of the town of Magüayo or Combined Inlet. Filled dark green areas indicate the approximate extent of vegetated floating peat mats at the time of study. 
management interventions performed by US Fish and Wildlife Service (USFWS) including excavation and removal of sediment and vegetation, draining, and burning [21] [22]. The overgrowth of Typha domingensis, Pistia stratiotes (water lettuce) and Eichhornia crassipies (water hyacinth) and the presence of extensive floating peat mats (Figure 1) continue to occupy large portions of the lagoon's surface area and cause losses of the open water habitat [21] [22].

\subsection{Sampling and Processing}

Water samples were collected in triplicate at mid-column depths from the channelized external sources of $\mathrm{P}$ and $\mathrm{N}$ that enter Laguna Cartagena. These external sources as shown in Figure 1 are: 1) distant rural domestic discharge from the hills to the north (Cerro Alto) of Laguna Cartagena (>1.5 km, point (a)); 2) local runoff from agricultural, domestic or industrial discharge to Margara Creek immediately south of where this creek passes under Road $306(<1.5 \mathrm{~km}$, point (b)); 3) Margara Canal - the continuance of Margara Creek (drainwater and runoff, point (c)); 4) Principal Drainage Canal adjacent to Road 305 at the UPR Lajas Agricultural Experiment Substation (near point (d)); and 5) Principal Drainage Canal in the Refuge to the west of the town of Magüayo, i.e., the Combined Inlet (drainwater and runoff) (near point (e)). All nutrients that enter the lagoon from this drainage basin come together and enter through the combined inlet canal, just west of point (e) that eventually flows west to Boquerón Bay.

Sampling occurred at two-week intervals from October 2013 through November 2014. All samples for P (SRP and TP) analyses were collected in glass bottles, preserved with $\mathrm{H}_{2} \mathrm{SO}_{4}$, and transported in ice to the Universidad del Turabo (now Ana G. Méndez University, Gurabo). These samples were stored at a low temperature and analyzed within 10 days collection using the persulfate digestion and ascorbic acid methods [23]. A Thermo Fisher Scientific, Genesys 20, with a wavelength range between 352 to $1100 \mathrm{~nm}$ was used to measure sample absorption at $880 \mathrm{~nm}$.

Rainfall data were obtained weekly from a rain gauge located approximately 6 $\mathrm{km}$ north of the lagoon in the upper portion of the watershed, a location representative of regional rainfall. Weekly rainfall data were recorded from September 2013 to November 2014. Dissolved oxygen (DO, mg/L), pH, Total dissolved solids (TDS, $\mathrm{mg} / \mathrm{L}$ ), temperature $\left({ }^{\circ} \mathrm{C}\right)$, and turbidity $(\mathrm{cm})$ were measured in the field for each sampling event. Instruments used for measurement of these parameters were a Hanna Instruments (HI 98186) for DO, AZ Instruments Corp, model 8685 for $\mathrm{pH}$ and temperature, an $\mathrm{EC} / \mathrm{TDS} /{ }^{\circ} \mathrm{C}$ Martini (EC 59) meter for TDS and a turbidity tube for turbidity. Nitrate $\left(\mathrm{NO}_{3}^{-}\right)$, nitrite $\left(\mathrm{NO}_{2}^{-}\right)$, and ammonia $\left(\mathrm{NH}_{3}\right)$ were determined using a HACH DR900 colorimeter. Nitrate $\left(\mathrm{NO}_{3}^{-}\right)$was measured using the cadmium reduction method 353.2. Nitrite $\left(\mathrm{NO}_{2}^{-}\right.$) was measured with the USEPA diazotization method, and ammonia using the salicylate method. All samples for $\mathrm{N}$ (nitrate, nitrite, and ammonia) were collected in glass bottles and stored at a low temperature and analyzed within 24 hours. 


\subsection{Statistical Analyses}

Mean SRP, TP, nitrate, nitrite, and ammonia values were calculated for each sample (triplicate sampling, $\mathrm{n}=3$ for each sample). ANOVA (Analyses of Variance) was used to determine significant differences between SRP, TP, nitrate, nitrite, and ammonia for the major canals that bring water to the lagoon. Correlation analyses were used to evaluate the possible correlations of SRP, TP, nitrate, nitrite, and ammonia with rainfall one week and two weeks prior sample collection. Results were considered significant when a $p$-value was less than 0.05 .

This study was conducted under the authorization of Biosafety Committee (IBC) Protocol B03-017-13 of the Ana G Mendez University System Office of Compliance.

\section{Results}

\subsection{Rainfall Conditions}

Monthly rainfall $(\mathrm{mm})$ for the Laguna Cartagena drainage basin recorded from September 2013 to November 2014 (Figure 2) indicated heavy rainfall during the months of August to November (except for Oct 2013), and allowed identification of specific rainfall events that occurred one and two weeks prior to water sample collection.

\subsection{Phosphorus and Nitrogen Concentrations from the Channelized External Sources that Enter Laguna Cartagena}

There were significant differences between SRP and TP for the major canals that bring water to the lagoon (One Way ANOVA: $p=0.000$ and $p=0.000$ ). The University of Puerto Rico (UPR) Agricultural Experimental Substation Drainage Canal (SRP mean $443.5 \mu \mathrm{g} / \mathrm{L}$ and TP mean $2469.3 \mu \mathrm{g} / \mathrm{L}$ ) and Cerro Alto northern hill sides (SRP mean $310.2 \mu \mathrm{g} / \mathrm{L}$ and TP mean $1626.2 \mu \mathrm{g} / \mathrm{L}$ ) provided the highest concentrations of SRP and TP (Figure 3) with Cerro Alto exhibiting the

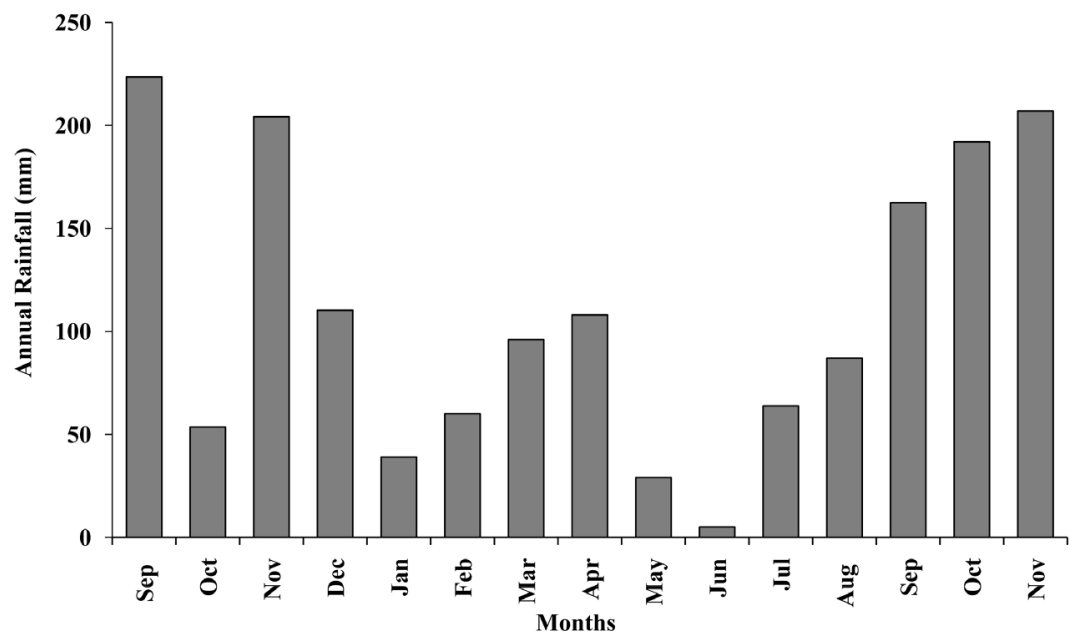

Figure 2. Total monthly rainfall for Lajas Puerto Rico, from September 2013 to November 2014 . 

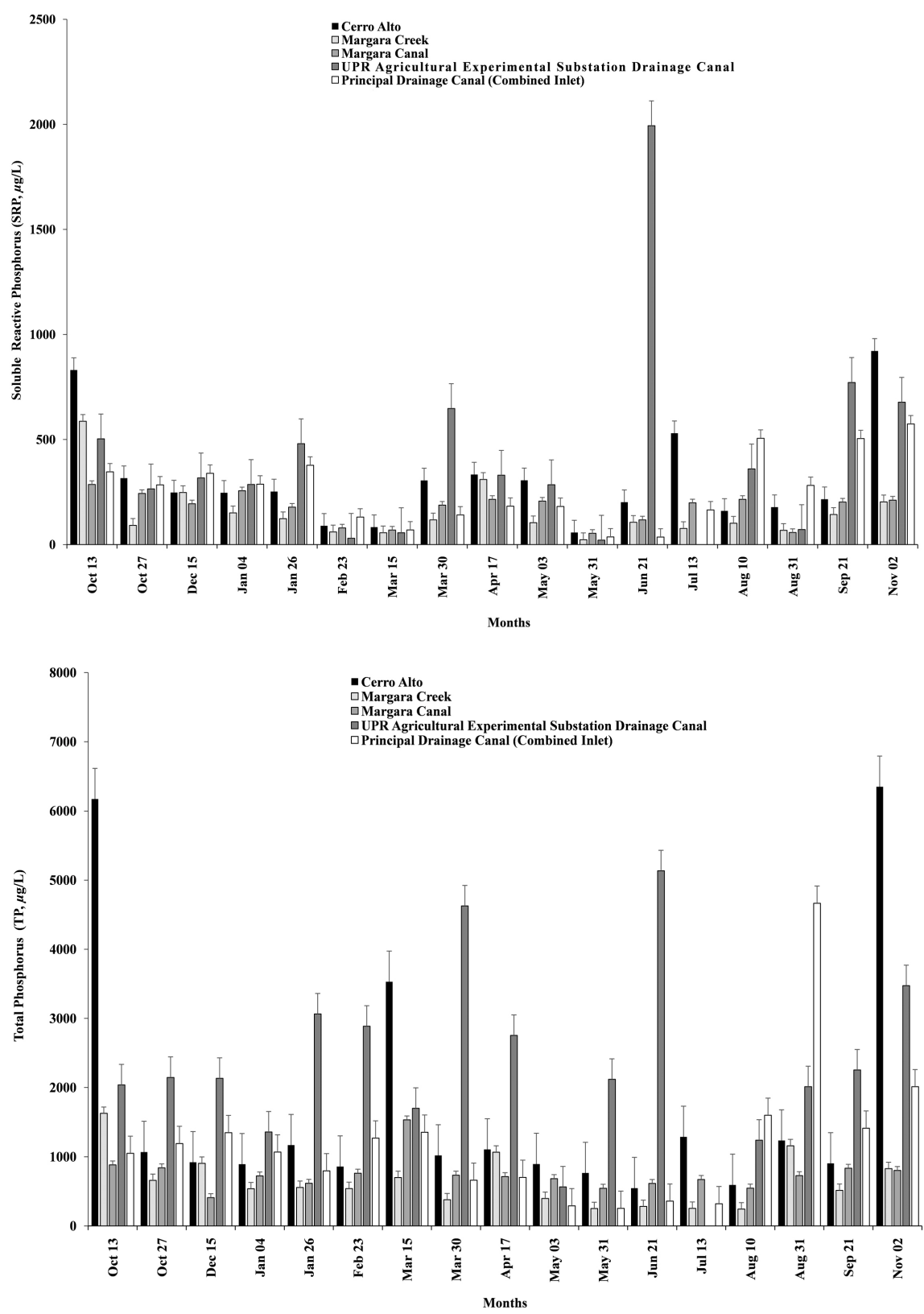

Figure 3. Soluble Reactive Phosphorus (SRP) and Total Phosphorus (TP) from (a) Cerro Alto; (b) Margara Creek immediately south of where this creek passes under Road 306; (c) Margara Canal; (d) Principal Drainage Canal at the UPR Lajas Agricultural Experimental Substation and the (e) Principal Drainage Canal at the town of Magüayo (or Combined Inlet) from 13 October 2013 to 2 November 2014.

highest concentrations of phosphorus $(\mathrm{P})$ in periods of high rainfall. The lowest SRP and TP concentrations were found in Margara Creek (SRP mean $151.1 \mu \mathrm{g} / \mathrm{L}$ and TP mean $641.2 \mu \mathrm{g} / \mathrm{L}$ ). On $23 \mathrm{Feb}, 15 \mathrm{Mar}$ and 31 May SRP was less than 100 $\mu \mathrm{g} / \mathrm{L}$ at all canals that bring water to Laguna Cartagena. However, on $23 \mathrm{Feb}$ the SRP for the Principal Drainage Canal in the Refuge to the west of Magüayo (the Combined Inlet) was $130.6 \mu \mathrm{g} / \mathrm{L}$. On 31 Aug, this canal presented an event of high TP $(4665.2 \mu \mathrm{g} / \mathrm{L})$ concentrations. 
For nitrite there were no significant differences between the channelized external sources of $\mathrm{P}$ that enter the lagoon (One Way ANOVA: $p=0.504$ ). Nitrate $\left(\mathrm{NO}_{3}^{-}\right)$and ammonia $\left(\mathrm{NH}_{3}\right)$ concentrations between the sampling sites were different (One Way ANOVA: $p=0.000$ and $p=0.002$, respectively). On 13 Jul, nitrate $\left(\mathrm{NO}_{3}^{-}\right)$was undetectable in all canals. The highest $\mathrm{NO}_{3}^{-}$concentrations were found in Margara Creek $\left(\mathrm{NO}_{3}^{-}\right.$mean $\left.=15.3 \mu \mathrm{g} / \mathrm{L}\right)$ and the UPR Agricultural Experimental Substation Drainage Canal $\left(\mathrm{NO}_{3}^{-}\right.$mean $\left.12.1 \mu \mathrm{g} / \mathrm{L}\right)$. Nitrate $\left(\mathrm{NO}_{3}^{-}\right)$concentrations were zero (undetectable) in the Combined Inlet, except for $23 \mathrm{Feb}(6.7 \mu \mathrm{g} / \mathrm{L})$ and $15 \mathrm{Mar} 2014(6.7 \mu \mathrm{g} / \mathrm{L})$ and 31 May $2014(3.3 \mu \mathrm{g} / \mathrm{L})$. The UPR Agricultural Experimental Substation Drainage Canal and Cerro Alto provided the highest concentrations of ammonia, with means of $496.7 \mu \mathrm{g} / \mathrm{L}$ and $82.2 \mu \mathrm{g} / \mathrm{L}$, respectively (Figure 4).

\subsection{Dissolved Oxygen, pH, Total Dissolved Solids, Temperature, and Turbidity}

Physicochemical parameters (Table 1) at each sampling point showed that the UPR Agricultural Experimental Substation and Cerro Alto had the highest measurements for turbidity $(12.1 \mathrm{~cm})$ and TDS $(434 \mathrm{mg} / \mathrm{L})$, respectively. Mean temperatures for all nonpoint source locations ranged from $25.5^{\circ} \mathrm{C}$ to $27.6^{\circ} \mathrm{C}$, (within acceptable regulatory limits $\left.\left(<32.2^{\circ} \mathrm{C}\right)[24]\right)$. Values for $\mathrm{pH}$ were 7.2 8.1, which are considered optimal.

The Principal Drainage Canal (Combined Inlet) had the lowest DO, with mean of $1.79 \mathrm{mg} / \mathrm{L}$ ) and range of $0.20 \mathrm{mg} / \mathrm{L}$ to $4.23 \mathrm{mg} / \mathrm{L}$.

\subsection{Phosphorus (P) and Nitrogen (N) Linkage with Heavy Rainfall Precipitation Events}

SRP and TP concentrations at Cerro Alto were significantly correlated $(p<0.05)$

Table 1. Means of physicochemical parameters monitored from 26 Jan 2014 through 02 Nov 2014 at the channelized external sources of P and N that enter Laguna Cartagena.

\begin{tabular}{|c|c|c|c|c|c|}
\hline \multirow[b]{2}{*}{ Location } & \multicolumn{5}{|c|}{ Physicochemical parameters } \\
\hline & $\begin{array}{c}\mathrm{DO} \\
(\mathrm{mg} / \mathrm{L})^{\mathrm{a}}\end{array}$ & $\mathrm{pH}^{\mathrm{b}}$ & $\begin{array}{c}\text { TDS } \\
(\mathrm{mg} / \mathrm{L})^{\mathrm{c}}\end{array}$ & $\begin{array}{l}\text { Temp } \\
\left({ }^{\circ} \mathrm{C}\right)^{\mathrm{d}}\end{array}$ & $\begin{array}{l}\text { Turbidity } \\
(\mathrm{cm})^{\mathrm{e}}\end{array}$ \\
\hline Cerro Alto & $8.4 \pm 4.3$ & $7.9 \pm 0.4$ & $434 \pm 120$ & $26.2 \pm 1.4$ & $76.1 \pm 36.2$ \\
\hline Margara Creek & $8.7 \pm 3.9$ & $8.1 \pm 0.6$ & $212 \pm 104$ & $27.8 \pm 1.4$ & $62.8 \pm 22.5$ \\
\hline Margara Canal & $8.6 \pm 3.7$ & $7.8 \pm 0.4$ & $229 \pm 70$ & $25.2 \pm 1.5$ & $95.1 \pm 13.0$ \\
\hline $\begin{array}{c}\text { UPR Agricultural } \\
\text { Experimental Substation } \\
\text { Drainage Canal }\end{array}$ & $7.2 \pm 5.2$ & $7.7 \pm 0.6$ & $269 \pm 75$ & $25.7 \pm 2.5$ & $12.1 \pm 13.9$ \\
\hline $\begin{array}{l}\text { Principal Drainage Canal } \\
\text { (Combined Inlet) }\end{array}$ & $1.8 \pm 1.3$ & $7.2 \pm 0.3$ & $255 \pm 65$ & $26.5 \pm 1.9$ & $69.2 \pm 27.2$ \\
\hline
\end{tabular}

( $\left.{ }^{\mathrm{a}}\right)$ DO: Dissolved oxygen was determined with a Hanna Instruments (HI 98186); $\left({ }^{\mathrm{b}}\right) \mathrm{pH}$ : $\mathrm{pH}$ was determined with an AZ Instruments Corp, model 8685; $\left(^{c}\right)$ TDS: Total Dissolved Solid was determined with the EC/TDS $/{ }^{\circ} \mathrm{C}$ (EC 59); $\left({ }^{\mathrm{d}}\right)$ Temp: Temperature was measured with an AZ Instruments Corp; $\left({ }^{\mathrm{e}}\right)$ Turbidity: The turbidity was determined by observation tube method; Higher numbers denote greater clarity, less turbidity. 

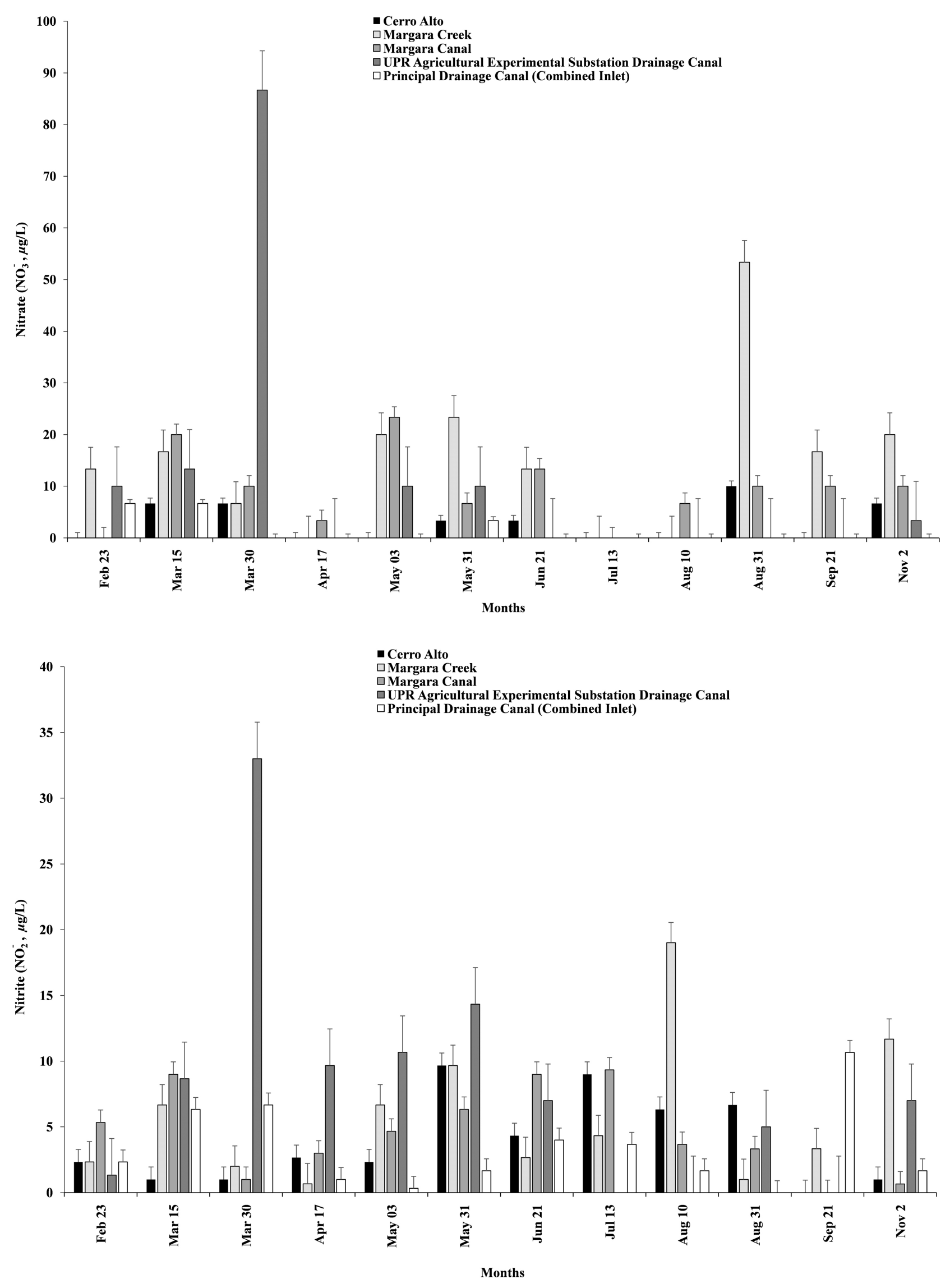


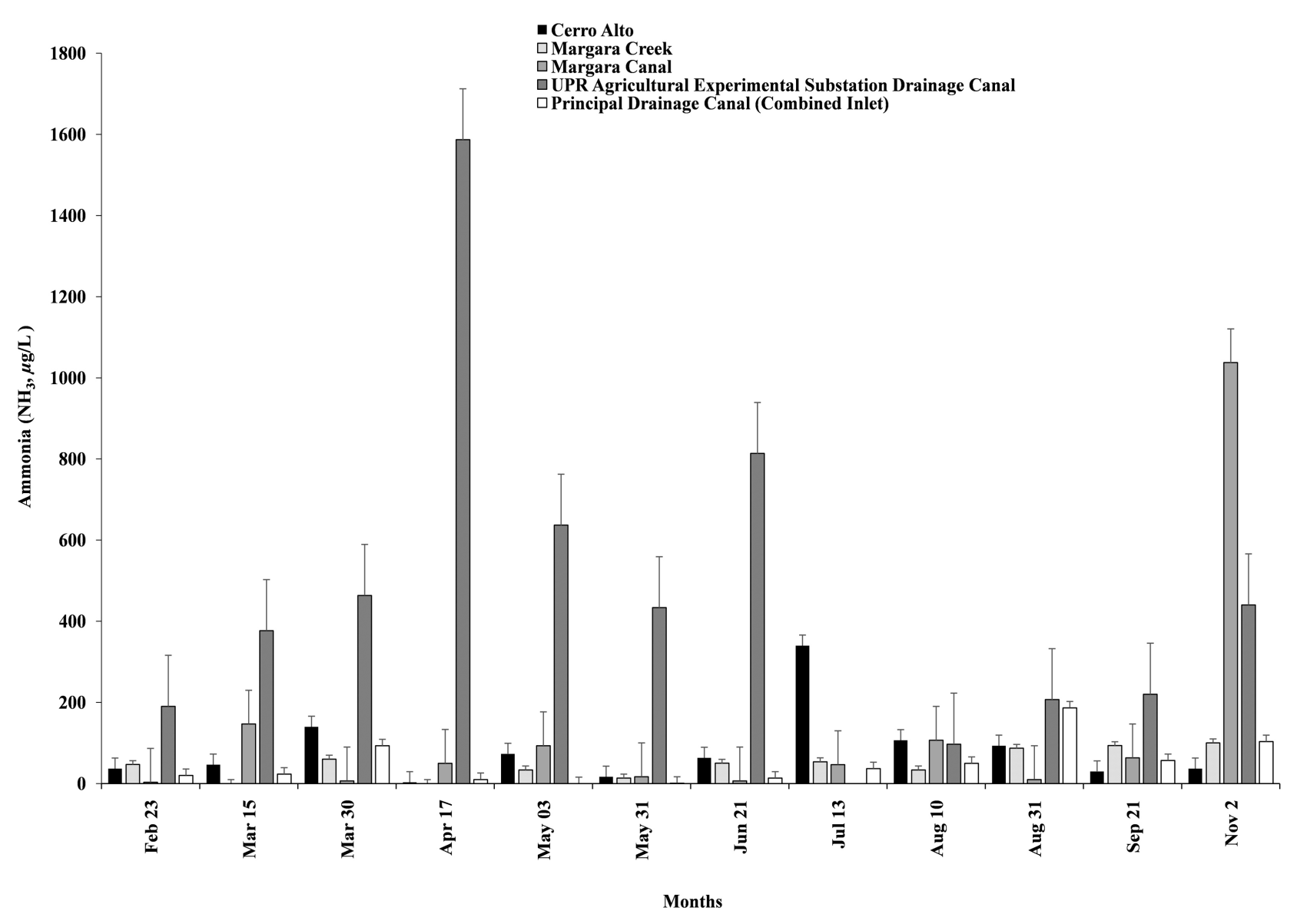

Figure 4. Nitrate $\left(\mathrm{NO}_{3}^{-}\right)$, nitrite $\left(\mathrm{NO}_{2}^{-}\right)$, and ammonia $\left(\mathrm{NH}_{3}\right)$ from (a) Cerro Alto; (b) Margara Creek immediately south of where this creek passes under Road 306; (c) Margara Canal; (d) Principal Drainage Canal at the UPR Lajas Agricultural Experimental Substation and the (e) Principal Drainage Canal at the town of Magüayo (or Combined Intet) from 23 February 2014 to 2 November 2014. Values are treated as zero if the measurable absorbance was less than the calibration range of the test.

with rainfall at one week ( $r=0.567, p=0.018 ; r=0.581, p=0.015$, respectively), and two weeks ( $r=0.536, p=0.026 ; r=0.502, p=0.040$, respectively) prior to sample collection (Table 2). Neither SRP nor TP were significantly correlated with rainfall event at Margara Creek, Margara Canal, or UPR Agricultural Experimental Substation Drainage Canal (Table 2). SRP at the Combined Inlet west of Magüayo was significantly correlated with both rainfall at one week before sampling, and two weeks before sampling $(r=0.784, p=0.000$ for one week and $r=0.751, p=0.001$ for two weeks, respectively) (Table 2). However, TP was not significantly correlated with either rainfall at one week, or two weeks before sampling (Table 2).

Nitrate $\left(\mathrm{NO}_{3}^{-}\right)$, nitrite $\left(\mathrm{NO}_{2}^{-}\right)$, and ammonia $\left(\mathrm{NH}_{3}\right)$ concentrations at the channelized external sources of nutrients that enter Laguna Cartagena were not significantly $(p>0.05)$ correlated with rainfall at one or two weeks prior to sample collection. However, ammonia $\left(\mathrm{NH}_{3}\right)$ at Margara Canal was significantly correlated with rainfall event at both one week $(r=0.848, p=0.000)$ and two weeks ( $r=0.789, p=0.002)$ prior to sampling (Table 3 ). 
Table 2. Correlations (r) of Soluble Reactive Phosphorus (SRP) and Total Phosphorus (TP) at the channelized external sources of phosphorus $(\mathrm{P})$ and nitrogen $(\mathrm{N})$ that enter Laguna Cartagena with rainfall events.

\begin{tabular}{ccc}
\hline Location (s) & \multicolumn{2}{c}{ Correlations } \\
\cline { 2 - 3 } SRP & $\mathrm{TP}^{\mathrm{b}}$ \\
\hline One week prior & $r=0.567, p^{d}=0.018$ & $r=0.581, p=0.015$ \\
Two weeks prior & $r=0.536, p=0.026$ & $r=0.502, p=0.040$ \\
& Margara Creek & \\
One week prior & $r=0.370, p=0.143$ & $r=0.240, p=0.353$ \\
Two weeks prior & $r=0.385, p=0.125$ & $r=0.317, p=0.215$ \\
Margara Canal & $r=0.359, p=0.157$ & \\
One week prior & $r=0.358, p=0.159$ & $r=-0.029, p=0.911$ \\
Two weeks prior & UPR Agricultural Experimental Substation Drainage Canal \\
One week prior & $r=0.109, p=0.678$ & $r=0.037, p=0.888$ \\
Two weeks prior & $r=0.092, p=0.724$ & $r=-0.042, p=0.873$ \\
& Principal Drainage Canal (Combined Inlet $)$ & \\
One week prior & $r=0.784, p=0.000$ & $r=0.165, p=0.526$ \\
Two weeks prior & $r=0.751, p=0.001$ & $r=0.225, p=0.385$ \\
\hline
\end{tabular}

a: Soluble Reactive Phosphorus; ${ }^{b}$ : Total Phosphorus; ${ }^{c}$ : Pearson correlation coefficient; ${ }^{d}: p$-value for the correlation.

Table 3. Correlations of nitrate $\left(\mathrm{NO}_{3}^{-}\right)$, nitrite $\left(\mathrm{NO}_{2}^{-}\right)$and ammonia $\left(\mathrm{NH}_{3}\right)$ at the channelized external sources of phosphorus $(\mathrm{P})$ and nitrogen $(\mathrm{N})$ that enter Laguna Cartagena with rainfall.

\begin{tabular}{ccccc}
\hline \multirow{2}{*}{ Location $(\mathrm{s})$} & \multicolumn{3}{c}{ Correlations } \\
\cline { 2 - 4 } & Nitrate $\left(\mathrm{NO}_{3}^{-}\right)$ & Nitrite $\left(\mathrm{NO}_{2}^{-}\right)$ & Ammonia $\left(\mathrm{NH}_{3}\right)$ \\
\hline One week prior & $r^{2}=0.040, p^{b}=0.902$ & $r=-0.325, p=0.303$ & $r=-0.151, p=0.640$ \\
Two weeks prior & $r=-0.002, p=0.995$ & $r=-0.390, p=0.210$ & $r=-0.281, p=0.377$ \\
& Margara Creek & \\
One week prior & $r=-0.132, p=0.683$ & $r=0.531, p=0.076$ & $r=0.460, p=0.133$ \\
Two weeks prior & $r=-0.077, p=0.813$ & $r=0.327, p=0.300$ & $r=0.415, p=0.180$ \\
& Margara Canal & \\
One week prior & $r=-0.052, p=0.872$ & $r=-0.515, p=0.086$ & $r=0.848, p=0.000$ \\
Two weeks prior & $r=-0.069, p=0.831$ & $r=-0.628, p=0.029$ & $r=0.789, p=0.002$ \\
UPR Agricultural Experimental Substation Drainage Canal \\
One week prior & $r=-0.213, p=0.506$ & $r=-0.259, p=0.416$ & $r=-0.135, p=0.675$ \\
Two weeks prior & $r=-0.285, p=0.370$ & $r=-0.251, p=0.432$ & $r=0.133, p=0.681$ \\
& Principal Drainage Canal $($ Combined Inlet $)$ & \\
One week prior & $r=-0.236, p=0.460$ & $r=0.170, p=0.598$ & $r=0.233, p=0.466$ \\
Two weeks prior & $r=-0.336, p=0.286$ & $r=0.082, p=0.801$ & $r=0.242, p=0.448$ \\
\hline
\end{tabular}

${ }^{a}$ : Pearson correlation coefficient; ${ }^{b}: p$-value for the correlation. 


\section{Discussion}

\subsection{Identification of Nonpoint of Water Sources That Enter Laguna Cartagena}

The channelized waterways that carry water to the lagoon can be classified as hypereutrophic (>100 $\mu \mathrm{g} / \mathrm{L})$ [11] for TP concentrations but oligotrophic $(<200$ $\mu \mathrm{g} / \mathrm{L})[11]$ for nitrogen (nitrogen depleted). Water Quality Standards set by the Puerto Rico Department of Natural and Environmental Resources for TP and nitrogen (nitrate, nitrite, and ammonia) establish limits for estuarine waters of $1000 \mu \mathrm{g} / \mathrm{L}$ and $5000 \mu \mathrm{g} / \mathrm{L}$, respectively [24]. By these standards, the Principal Drainage Canal at the UPR Agricultural Experimental Substation exceeded the limits for total phosphorus (TP) on 15 of 17 occasions, with concentrations between $1239.6 \mu \mathrm{g} / \mathrm{L}$ and $5133.8 \mu \mathrm{g} / \mathrm{L}$. Alto exceeded these limits on 9 of $17 \mathrm{occa}-$ sions, with TP concentrations between $1020.3 \mu \mathrm{g} / \mathrm{L}$ and $6350.4 \mu \mathrm{g} / \mathrm{L}$. However, the main channelized external influent water to the lagoon did not exceed regulatory limits for nitrogen.

There was a significant difference between SRP and TP for the major canals that bring water to the lagoon. Agriculture (rice and cattle) is the predominant land use at the UPR Lajas Agricultural Experiment Substation, the predominant nonpoint source of nutrient pollution (Soluble Reactive Phosphorus (SRP), Total Phosphorus (TP), and ammonia $\left(\mathrm{NH}_{3}\right)$ ) in the principal channelized water sources to the lagoon. Nutrients are likely derived from fertilizers applied to the Substation's rice fields and also as a result of high a density livestock (dairy cattle), and the nitrogenous wastes from the cattle oxidation pond. Intensive agricultural practices use fertilizers containing high concentrations of nutrients $(P$ and $\mathrm{N}$ ), which show up in the runoff [25].

The upper Lajas Valley area (between Road 101 and the Principal Irrigation Canal) is a large productive drainage basin with beef cattle and pineapple currently as the major crops, but previously (until the late 1990s) dominated by sugar cane and pineapple.

Flux rates of nutrients to water from fertilizer and manure depend on various factors including specific farming practices, the nature and amount of fertilizer applied, soil type, leaving tilled soil exposed to rainfall and overland flow, soil drainage, vegetative cover, season, and timing of rainfall after application [26]. Farmers may overfertilize because they are unaware of the specific nutrient content of their soils or the needs of their crops [27].

The second important cause of external surface water degradation (Soluble Reactive Phosphorus (SRP), Total Phosphorus (TP) and ammonia $\left(\mathrm{NH}_{3}\right)$ is the discharge from rural households, as indicated from the results of nearby Cerro Alto. Most homes in the drainage basin discharge greywater directly to the environment-to the hillsides behind the homes. Lakes and streams near urban suburban and rural areas are often adversely affected by storm water runoff [28] [29]. These storm water runoff are important diffuse sources of phosphorus and nitrogen [28] [29]. 
Rural domestic discharges include household cleaning products, the septic leachate and runoff from failed septic systems (wastewater), and especially the direct discharge of rural domestic greywater to the hillside pastures that drain through the small tributaries that converge at the Cerro Alto sampling point. Other discharges may include urban runoff from construction, and runoff from lawns and streets. Most of the domestic waste collecting tanks (septic tanks) in Lajas are constructed without any lining materials and can leak liquid waste to the ground, causing nutrients to overflow to open canals during the rainy season. However, a lack of corresponding high $\mathrm{N}$ concentrations suggests that the elevated TP levels seen at the Cerro Alto location and lower sampling sites result from soaps and phosphate detergents used by the residences that directly discharge their domestic greywater effluents to the environment.

The water quality results in this study showed that dissolved oxygen (DO) levels measured in all canals were more than $2 \mathrm{mg} / \mathrm{L}$, (13 of 17 occasions). Such low DO concentrations will not support fish from in the Principal Drainage Canal at the UPR Agricultural Experimental Substation. DO levels with value from 8 to $11 \mathrm{mg} / \mathrm{L}$ are usually required in a nutritionally balanced stream, while $4 \mathrm{mg} / \mathrm{L}$ is a minimum value needed to support most species of fish [27]. On few occasions the DO levels measured in the canals were greater than $11 \mathrm{mg} / \mathrm{L}$. This is not surprising, given that DO depends on the movement of aerated water from turbulence and the currents caused by wind, water flow, and thermal upwelling [1].

The high turbidity levels $(1.20$ to $52.87 \mathrm{~cm}$ ) from the Principal Drainage Canal at the UPR Agricultural Experimental Substation are due to the high amounts of suspended inorganic and organic matter, including nutrients and pollutants. The overall $\mathrm{pH}$ values for all samples were basic (alkaline).

In general, these results demonstrated the impact of humans on the lagoon ecosystem by the introduction of chemicals and biological constituents to the water that flows to the lagoon.

\subsection{Phosphorus (P) and Nitrogen (N) Linkage with Heavy Rainfall Events}

SRP concentrations at Cerro Alto and the Principal Drainage Canal in the Refuge of Magüayo (the Combined Inlet) were significantly correlated with rainfall events at one week ( $r=0.567, p=0.018 ; r=0.784, p=0.000$, respectively), and two weeks ( $r=0.536, p=0.026 ; r=0.751, p=0.001$, respectively) prior to sample collection. Also, TP concentrations at Cerro Alto were significantly correlated with rainfall at one week ( $r=0.581, p=0.015)$, and two weeks $(r=0.502, p$ $=0.040)$ prior sample collection.

Nitrate $\left(\mathrm{NO}_{3}^{-}\right)$, nitrite $\left(\mathrm{NO}_{2}^{-}\right)$, and ammonia $\left(\mathrm{NH}_{3}\right)$ concentrations at the channelized external sources of nutrients that enter Laguna Cartagena were not significantly $(p>0.05)$ correlated with rainfall events at one and two weeks prior to sampling collection, except for ammonia at Margara Canal was significantly correlated with rainfall events at one week $(r=0.848, p=0.000)$ and two weeks 
$(r=0.789, p=0.002)$ prior to sampling. Although increased precipitation is related to $\mathrm{N}$ loading in surface water [30], study of the $\mathrm{N}$ cycle is complicated due to natural factors such as vegetation or soil cover, soil properties, geology, and morphology [15] [31] that can affect $\mathrm{N}$ valence states $(-3$ to +5$)$.

From Cerro Alto to Margara Canal, phosphorus (P) concentrations are likely to be less because nutrients may be diluted and flushed away rapidly downstream. However, concentrations in the Combined Inlet at Magüayo increase again due to high phosphorus concentrations from the UPR Agricultural Experimental Substation. This study also found no evidence of any discharge of "sewage”, per se, or concentrated nitrogenous wastes from the adjacent Magüayo neighborhood. The channelized external sources of $\mathrm{P}$ and $\mathrm{N}$ that enter Laguna Cartagena through the Principal Drainage Canal (Combined Inlet) in the Refuge collect nonpoint sources that have had no treatment or control. In general, precipitation is strongly associated with high levels of $\mathrm{P}$ loading that enters Laguna Cartagena. Relationships of precipitation with $\mathrm{P}$ loading also have been noted in studies elsewhere [29].

\section{Conclusions}

The channelized external sources of SRP and TP that enter Laguna Cartagena are important causes of external surface water degradation due to added high concentrations of nutrients from agriculture and discharge from rural households. In some instances, the results indicate that TP was in excess of the acceptable level as defined by the environmental regulations, while $\mathrm{N}$ concentrations were well below the specific allowable levels of discharge as defined by the Water Quality Standards of the Environmental Quality Board of Puerto Rico. Results of this study indicate that continuing human activities, including domestic greywater discharge, are both the direct and indirect causes of ongoing deterioration of the lagoon ecosystem. Unfortunately, Laguna Cartagena has been impacted by several cultural eutrophication consequences that include severe overgrowth of Typha domingensis and extensive floating peat mats that have occupied large portions of the available volume and surface area of the lagoon since the second half of the $20^{\text {th }}$ Century, when P-laden drain water from inorganic agricultural fertilizer was discharged to the system. Laguna Cartagena is $\mathrm{N}$ depleted yet $\mathrm{P}$ hypereutrophic. The productivity of the lagoon's water column is limited by $\mathrm{N}$ rather than $\mathrm{P}$, and therefore, are highly uncharacteristic of freshwater wetlands.

Sustainable restoration, management and conservation of Laguna Cartagena will require changes in land management and land use in the drainage basin and will require political decision makers to both enforce current regulatory standards (e.g. for domestic discharge) as well as apply new regulatory standards to decrease the nonpoint pollution to be comparable to proposed water quality standards for Florida lakes (discharge limits of $42 \mu \mathrm{g} / \mathrm{L}$ TP in canals). This will require further testing to quantify nutrient loads with greater specificity; conti- 
nuous water quality monitoring; and creation of active community engagement in restoration planning of Laguna Cartagena.

\section{Acknowledgements}

Many people contributed to this study during the fieldwork, laboratory analysis and data processing. We thank Karla Montañez for the help in the lab and the field. We also wish to thank the Universidad del Turabo (now Ana G. Méndez University, Gurabo) for providing use of laboratory facilities, materials, and partial support for the research. Thanks so much also to Dr. Brenda Carolina Torres Velásquez for her support with statistical analyses.

\section{Conflicts of Interest}

The authors declare no conflict of interest.

\section{References}

[1] Ji, Z.G. (2017) Hydrodynamics and Water Quality. John Wiley and Sons, Hoboken. https://doi.org/10.1002/9781119371946

[2] Ramsar Convention on Wetlands (2018) Global Wetland Outlook: States of the World's Wetlands and Their Services to People. Ramsar Convention on Wetlands, Switzerland.

[3] Delkash, M., Al-Faraj, F.A.M. and Scholz, M. (2018) Impacts of Anthropogenic Land Use Changes on Nutrient Concentrations in Surface Waterbodies: A Review. CLEAN-Soil, Air, Water 46, Article ID: 1800051.

[4] Al-Taai, S.H.H. (2021) Water Pollution: Its Causes and Effects. IOP Conferences Series. Earth and Environmental Science, 790, Article ID: 012026. https://doi.org/10.1088/1755-1315/790/1/012026

[5] Islam, F., Lim, Q., Uddin-Ahmed, Z., Zappi, M.E., Yao, L. and Dianchen-Gang, D. (2018) Nonpoint Source Pollution. Water Environmental Research, 90, 1872-1898. https://doi.org/10.2175/106143017X15131012188033

[6] Liu, Y., Li, H., Cui, G. and Cao, Y. (2020) Water Quality Attribution and Simulation of Non-Point Source Pollution Load Flux in the Hulan River Basin. Scientific Reports, 10, Article No. 3012. https://doi.org/10.1038/s41598-020-59980-7

[7] Tang, X., Li, R., Han, D. and Scholz, M. (2020) Response of eutrophication development to variations in nutrients and hydrological regime: A case study in the Changjian River (Yangtze) basin. Water 12, Article No. 1634. https://doi.org/10.3390/w12061634

[8] Boesch, D.F. (2019) Barriers and Bridges in Abating Coastal Eutrophication. Frontiers in Marine Science, 6, Article No. 123. https://doi.org/10.3389/fmars.2019.00123

[9] González-Rivas, E.J., Roldán-Pérez, G., Tundisi, J.G., Vammen, K., Örmeci, B. and Forde, M. (2020) Eutrophication: A Growing Problem in the Americas and the Caribbean. Brazilian Journal of Biology, 80, 688-689. https://doi.org/10.1590/1519-6984.200001

[10] Massri, Z., Nunn, A.N., Ghane, E., Seybold, A., Piwarski, J.R., Adams, J. and Asher, J. (2021) Water Sampling Holding Times at Appropriate Temperature, Filtering, and Storage Conditions for Accurate Analysis of Soluble Reactive Phosphorus. 2021 ASABE Annual International Virtual Meeting, St Joseph Missouri, 12-16 July 2021, Article ID: 2101116. 
[11] Vollenweider, R.A. (1968) Water Management Research: Scientific Fundamentals of the Eutrophication of Lakes and Flowing Waters, with Particular Reference to Phosphorus and Nitrogen as Factors in Eutrophication. Organization for Economic Cooperation and Development, Paris, Report No. DAS/CSI/68.27.

[12] Roland, F.A.E, Darchambeau, F., Borges, A.V., Morana, C., De Brabandere, L., Thamdrup, B. and Crowe, S.A. (2017) Denitrification, Anaerobic Ammonium Oxidation, and Dissimilatory Nitrate Reduction to Ammonium in an East African Great Lake (Lake Kivu). Limnology and Oceanography 63, 687-701. https://doi.org/10.1002/lno.10660

[13] Zhang, X., Ward, B.B. and Sigman, D.M. (2020) Global Nitrogen Cycle: Critical Enzymes, Organisms, and Processes for Nitrogen Budgets and Dynamics. Chemical Reviews, 120, 5308-5351. https://doi.org/10.1021/acs.chemrev.9b00613

[14] Wetzel, R.G. (2001) Limnology: Lake and River Ecosystems. Academic Press Elsevier, San Diego.

[15] Hamid, A., Bhat, S.U. and Jehangar, A. (2020) Local Determinants Influencing Stream Water Quality. Applied Water Science, 10, Article No. 24.

https://doi.org/10.1007/s13201-019-1043-4

[16] Sharma, R. and Malaviya, P. (2021) Management of Stormwater Pollution Using Green Infrastructure: The Role of Rain Gardens. Wiley Interdisciplinary Reviews Water, 8, Article No. e1507. https://doi.org/10.1002/wat2.1507

[17] Weaver, P.L. and Schwagerl, J.J. (2009) US Fish and Wildlife Services Refuges and Other Nearby Reserves in Southwestern Puerto Rico. General Technical Report IITF-40, U.S. Department of Agriculture Forest Service, Institute of Tropical Forestry, San Juan. https://doi.org/10.2737/IITF-GTR-40

[18] Ramírez-Toro, G.I. and Minnigh, H.A. (1997) Drainwaters: Biological Responses to Water Quality. III Regional AIDIS Congress for North America and the Caribbean, San Juan, 7-12 June 1997, 1-7.

[19] Ramírez-Toro, G.I., Minnigh, H.A., Troche, F., Ramos-Morales, L. and Rivera-Matos, O. (1997) Bacteriological Water Quality Indicators in Natural Waters. III Regional AIDIS Congress for North America and the Caribbean, San Juan, 7-12 June 1997, 8-15.

[20] Schaffner, F.C. (2007) Accelerated Terrestrialization of a Subtropical Lagoon: The Role of Agency Mismanagement. 32nd Annual Conference on Ecosystems Creation and Restoration, Tampa, 27-28 October 2005, 92-110.

[21] Sánchez-Colón, Y.M. (2015) Identifying Nonpoint Sources of Phosphorus (P) and Nitrogen (N) Pollution and Dynamics, Internal Eutrophication and Anoxia Variability at a Tropical Freshwater Wetland (Laguna Cartagena, Puerto Rico). PhD Dissertation, Universidad del Turabo, Puerto Rico.

[22] Sánchez-Colón, Y.M. and Schaffner, F.C. (2021) A Case Study of the Effects of Management Interventions on the Phosphorus Dynamics at a Coastal, Eutrophic, Caribbean Lagoon (Laguna Cartagena, Puerto Rico). Water 13, Article No. 449. https://doi.org/10.3390/w13040449

[23] American Public Health Association, American Water Works Association, Water Environment Federation (2017) Standard Methods for the Examination of Water and Wastewater. Joint Editorial Board, Baltimore.

[24] Department of Natural and Environmental Resources (2019) Puerto Rico Water Quality Standards Regulations.

https://www.epa.gov/sites/production/files/2014-12/documents/prwqs.pdf

[25] United States Environmental Protection Agency (2020) The Sources and Solutions: 
Agriculture.

https://www.epa.gov/nutrientpollution/sources-and-solutions-agriculture

[26] Carpenter, S.R., Booth, E.G. and Kucharik, C.J. (2018) Extreme Precipitation and Phosphorus Loads from Two Agricultural Watersheds. Limnology and Oceanography, 63, 1221-1233. https://doi.org/10.1002/lno.10767

[27] Cunningham, W.P. and Cunningham, M.A. (2020) Environmental Science: A Global Concern. McGraw Hill Education, New York.

[28] da Silva, F.L., Stefani, M.S., Smith, W.S. Schiavone, D.C., da Cunha-Santino, M.B. and Bianchini, I. (2020) An Applied Ecological Approach for the Assessment of Anthropogenic Disturbances in Urban Wetlands and the Contributor River. Ecological Complexity, 43, Article ID: 100852. https://doi.org/10.1016/j.ecocom.2020.100852

[29] United States Environmental Protection Agency (2020) Basic Information about Nonpoint Source Pollution (NPS). United States Environmental Protection Agency, Washington DC.

https://www.epa.gov/nps/basic-information-about-nonpoint-source-nps-pollution

[30] Sinha, E., Michalak, A.M. and Balaji, V. (2017) Eutrophication Will Increase during 21st Century as a Result of Precipitation Changes. Sciences, 357, 405-408. https://doi.org/10.1126/science.aan2409

[31] Yadav, S.K., Dubey, A., Singh, S.K. and Yadav, D. (2020) Spatial Regionalisation of Morphometric Characteristics of Mini Watershed of Northern Foreland of Peninsular India. Arabian Journal of Geosciences 13, Article No. 435. https://doi.org/10.1007/s12517-020-05365-Z 